\title{
A reassessment of the taxonomic status of Paraglyptodon Castellanos, 1932 (Mammalia, Cingulata, Glyptodontia)
}

\author{
Laura E. Cruz $^{\text {a, }}$, Juan C. Fernicola ${ }^{\mathrm{a}, \mathrm{b}}$, Matias Taglioretti ${ }^{\mathrm{c}}$, Nestor Toledo ${ }^{\mathrm{d}}$ \\ a CONICET, Consejo Nacional de Investigaciones Científicas y Técnicas-Museo Argentino de Ciencias Naturales "Bernardino Rivadavia”, Av. Ángel Gallardo \\ 470, Capital Federal, C1405DJR, Argentina \\ b Departamento de Ciencias Básicas, Universidad Nacional de Luján, Ruta 5 y Avenida Constitución, 6700, Luján, Buenos Aires, Argentina \\ c CONICET-Instituto de Geología de Costas y del Cuaternario, Facultad de Ciencias Exactas y Naturales, Universidad Nacional de Mar del Plata, Deán Funes \\ 3350, B7602AYL, Mar del Plata, Buenos Aires, Argentina \\ d CONICET-División Paleontología Vertebrados, Unidades de Investigación Anexo Museo FCNyM-UNLP, Avenida 60 y 122, B1900FWA, La Plata, Argentina
}

\section{A R T I C L E I N F O}

\section{Article history:}

Received 21 September 2015

Received in revised form

4 November 2015

Accepted 20 November 2015

Available online 25 November 2015

\section{Keywords:}

Osteoderm

Paraglyptodon

Glyptodon

Glyptodontidae

"Uquiense"

Chapadmalalan

\begin{abstract}
A B S T R A C T
Castellanos described and published about new genera of glyptodonts, according to a phylogenetic scheme mainly based on the evolution of the external surface of the dorsal carapace. Among these new genera, Castellanos proposed Paraglyptodon as the predecessor of Glyptodon, and included within Paraglyptodon all known species of Glyptodontinae recovered from "horizontes pre-Ensenadenses", and within Glyptodon all known species from "Horizontes pampeanos", restricting the latter to the Quaternary. All the species that belong to Paraglyptodon, that is Paraglyptodon chapalmalensis, Paraglyptodon uquiensis, Paraglyptodon dubius, and Paraglyptodon paranensis were established based on one, two or few osteoderms, mostly from the dorsal carapace. Regarding P. paranensis and P. dubius, Oliva and collaborators consider the first as a nomen vanum, representing an indeterminate Glyptodontinae, and the second as a synonym of $P$. chapalmalensis. Upon re-examination of the holotypes of $P$. chapalmalensis and $P$. uquiensis together with their comparison with other well-known specimens of glyptodonts, mainly with Glyptodon (of both juvenile and adult stages), we found the same ornamentation in different sections of the dorsal carapaces, particularly in P. chapalmalensis and in juvenile stages of Glyptodon spp. We could not identify features that would allow us to make a distinction between the holotype of $P$. uquiensis and Glyptodon spp. Therefore, we consider that a new taxon guide for naming the Upper Chapadmalalan biozone is necessary. The biostratigraphic range of Glyptodon could possibly be extended to the late Pliocene. However, new records and studies are needed to verify the existence of this taxon in the Chapadmalalan Stage/Age in its type locality.
\end{abstract}

๑ 2015 Elsevier Ltd. All rights reserved.

\section{Introduction}

The Cingulata, comprising armadillos, pampatheres and glyptodonts, together with Tardigrada and Vermilingua, integrates the Xenarthra order, one of the most conspicuous South American clades of placental mammals. One of the most noticeable features of Cingulata is the presence of an osseous exoskeleton, which comprises a cephalic shield, a tail armor and a dorsal carapace. These structures consist of hundreds of articulated osteoderms, a

\footnotetext{
* Corresponding author.

E-mail addresses: cruzlaurae@gmail.com (L.E. Cruz), jctano@yahoo.com (J.C. Fernicola), paleomat@gmail.com (M. Taglioretti), ntoledo@fcnym.unlp.edu.ar (N. Toledo).
}

feature that increases their potential for fossilization and has made osteoderms play an important role in the taxonomy of the group. A large number of genera and species of glyptodonts were established based only on a few or even one osteoderm (Fernicola and Porpino, 2012). Therefore, as was mentioned by Ameghino (1889) and, more recently, by other authors (e.g. Duarte, 1997; Soibelzon et al., 2006), it is very probable that the specific diversity within the genera has been overestimated, and this may even apply to the genera as well. This problem also affects the genus Paraglyptodon (Castellanos, 1932), which currently contains two species, Paraglyptodon chapalmalensis Ameghino in Rovereto (1914) and Paraglyptodon uquiensis Castellanos (1953a).

The taxonomic history of Paraglyptodon started at the beginning of the twentieth century, when Florentino Ameghino (1908) 
proposed Glyptodon chapalmalensis based on a fragment from the dorsal carapace comprising sixteen osteoderms, which he collected in the Atlantic Coast of Buenos Aires Province, Argentina (Fig. 1) (Ameghino, 1908). Ameghino (1908) characterized this species as very small and the oldest of the group. This description of the species was expanded by Rovereto (1914, p. 206, pl. XXVII, Fig. 1), who figured the mentioned fragment was part of the dorsal carapace. Castellanos (1932) considered G. chapalmalensis (Ameghino in Rovereto (1914)) as the type species of his new genus Paraglyptodon. According to Castellanos (1932), P. chapalmalensis osteoderms were smaller than those of Glyptodon and their external ornamentation, formed by central and peripheral figures, have a shallower relief and were separated by broader sulci. Later, Castellanos (1953a) formally described P. uquiensis based on fossil specimens collected between 1909 and 1921 in different field works in Uquía (Jujuy province, Argentina, Fig. 1). For Castellanos, this species was a characteristic fossil for his "Piso Uquiense" (1953a). This taxonomic proposal was followed by several authors, either from a standpoint of biostratigraphic (e.g. Cione and Tonni, 1995a,b, 1999, 2005, Carlini and Scillato Yane, 1999; Reguero and Candela, 2008, 2011; Reguero et al., 2007), or taxonomic approaches (e.g. Scillato-Yané et al., 1995; Carlini and Scillato Yane, 1999; Reguero and Candela, 2008, 2011; Reguero et al., 2007). Thus, in most of these papers, the above-mentioned authors cited $P$. chapalmalensis and $P$. uquiensis as coming from pre-Ensenadan levels, in particular from the Chapadmalalan and "Uquian" stage/ age, respectively. Moreover, when Castellanos (1953a) established P. uquiensis, he recognized two more species, Paraglyptodon dubius and $P$. paranensis, based on two and one osteoderms, respectively. More recently, Oliva et al. (2010), in a review of the Glyptodontinae from Chapadmalalan Stage/Age, considered $P$. dubius as a synonym of $P$. chapalmalensis and $P$. paranensis as a nomen vanum.

This work presents a taxonomic review of the two species currently recognized, $P$. chapalmalensis and $P$. uquiensis, as well as a discussion focused on type specimens. Stratigraphic and biostratigraphic interpretations about these materials are also discussed here.

Institutional Abbreviations-MACN-A, Museo Argentino de Ciencias Naturales "Bernardino Rivadavia”, Colección Nacional de Ameghino, Ciudad Autónoma de Buenos Aires, Argentina; MACNPv, Museo Argentino de Ciencias Naturales "Bernardino Rivadavia”, Colección Nacional de Paleovertebrados, Ciudad Autónoma de Buenos Aires, Argentina; MCA, Museo Carlos Ameghino, Mercedes, Buenos Aires, Argentina; MCNC-PV, Museo Provincial de Ciencias Naturales “Dr. Arturo U. Illía”, Córdoba, Argentina; MLP, Museo de La Plata, La Plata, Buenos Aires, Argentina; MMP, Museo Municipal de Ciencias Naturales "Lorenzo Scaglia", Mar del Plata, Buenos Aires, Argentina.

Anatomical Abbreviations-cf, central figure; cs, central sulcus; Ml, upper molariform; pf, peripheral figures; rs, radial sulcus; ss, sutural surface.

\section{Materials and methods}

Paraglyptodon chapalmalensis: The holotype of this species is a single specimen that consists of a dorsal carapace fragment comprising 16 osteoderms (Fig. 2). This material is housed in the Colección Nacional de Paleovertebrados at the Museo Argentino de Ciencias Naturales "Bernardino Rivadavia" (MACN-Pv) with the number MACN-Pv 6162. According to the museum catalogue, Ameghino collected it in 1908.

Ameghino (1908) recognized this species as G. chapalmalensis

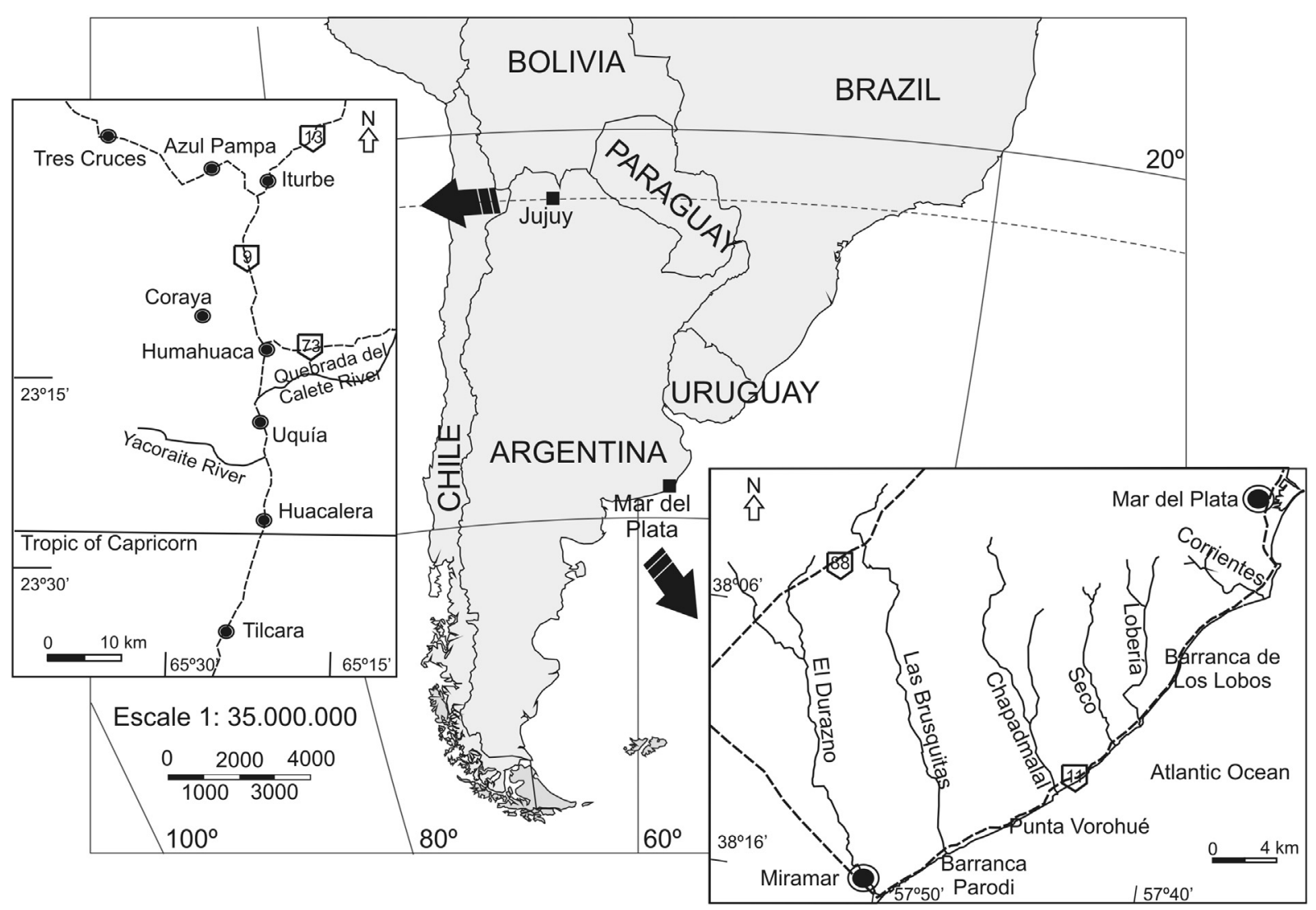

Fig. 1. Localities in southern South American mentioned in the text. 


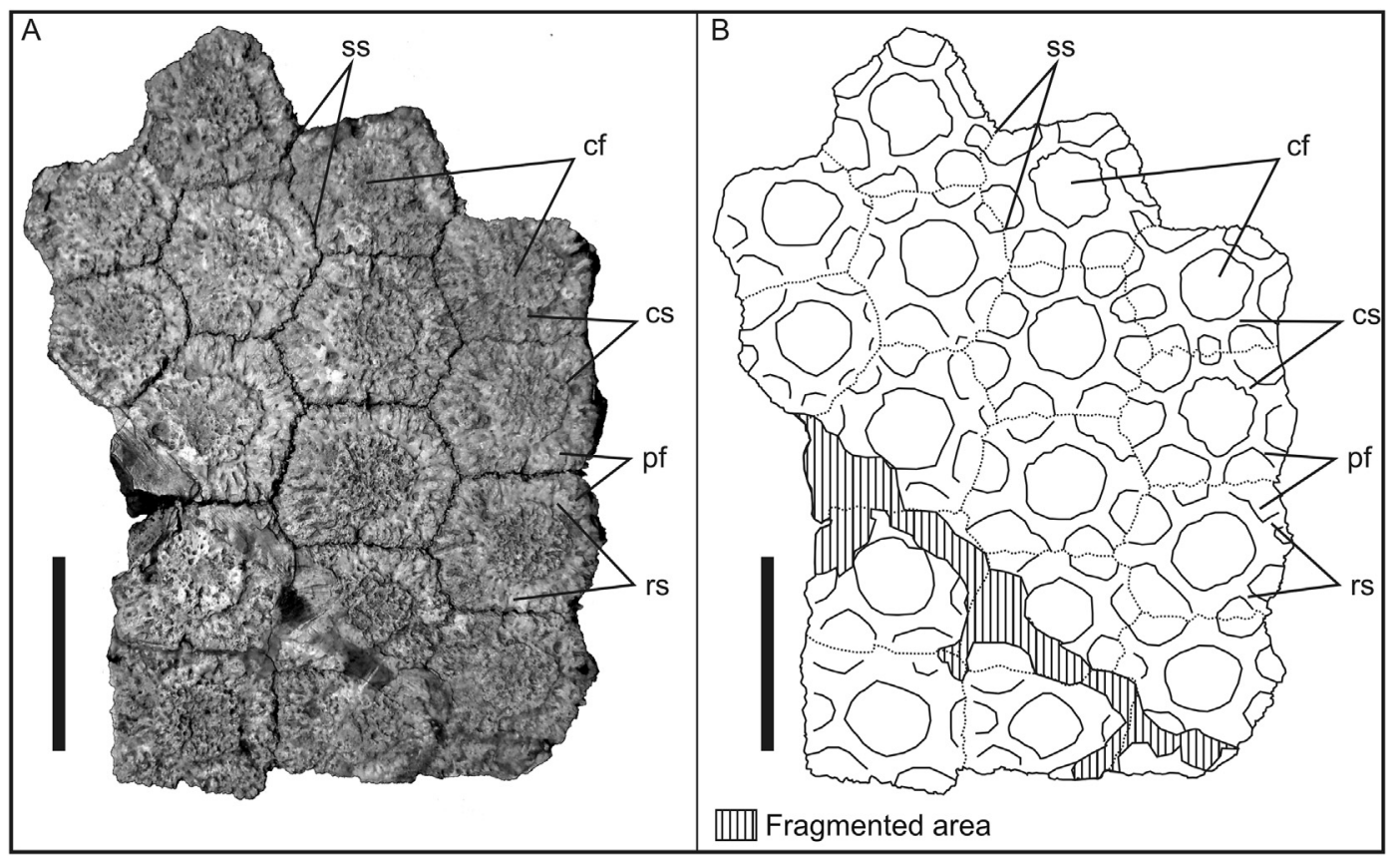

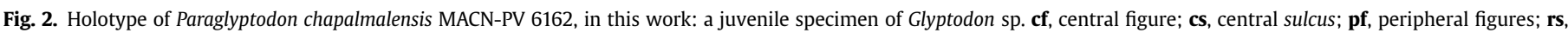
radial sulcus; ss, sutural surface. Scale bar: $5 \mathrm{~cm}$.

and together with more of seventy taxa, established his "Horizonte Chapadmalense". Most of the specimens that were studied by Ameghino (1908) were collected by himself during three field trips he took in 1908 to the coastal cliff located between the Corrientes and Las Brusquitas creeks, southwest of Mar del Plata city (Chapadmalal area, Buenos Aires, Argentina. Fig. 1). Ameghino (1908, p. 353) called this area "Barranca de Los Lobos". These materials collected by Ameghino were not the only specimens he studied, as he had also bought some specimens in 1899 from an anonymous collector (Ameghino, 1908, p. 354). In fact, Ameghino (1908) and later Rovereto (1914) recognized that the specimens of the "Horizonte Chapadmalense" belonged to three collections: (i) Ameghino's personal collection (currently at MACN-A), (ii) specimens collected by Ameghino during his expeditions, deposited in the Vertebrate Paleontology collection at the MACN (currently at MACN-Pv), and (iii) some specimens from the Vertebrate Paleontology collection at the Museo de La Plata (MLP). In this context, it is necessary to discuss if the type specimen of $P$. chapalmalensis was one of the specimens bought by Ameghino or not.

At present, we are unable to establish which of the specimens of the MLP are those mentioned by Ameghino since none of the studied specimens in that collection match Ameghino's original descriptions. Regarding the other collections, historical evidence allows us to assume that the specimens purchased by Ameghino in 1899 formed part of his private collection, which was acquired by the "Estado Nacional Argentino" (Argentine National state) during the 1930's. This collection is in MACN-A, where Ameghino held the post of Director from 1902 until his death in 1911. Within this context, the specimens he collected during his field trips to the Chapadmalal area during 1908 were most likely kept in this institution, as part of the "Colección Nacional de Paleovertebrados" (MACN-Pv). Therefore, we conclude here that MACN-PV 6162 had been collected by Ameghino himself and, hence, not bought. Ameghino (1908) did not provide the precise geographical information of the type specimen of this species; he only positioned the species in his "Horizonte Chapadmalense" from the Atlantic Cost. He described in detail the area of Chapadmalal, located between
Corrientes and Las Brusquitas creeks (Fig. 1), as two horizons clearly separated by sedimentary and faunistic features: "Horizonte Chapalmalense" (the basal one) and "Horizonte Ensenadense" (overlying the preceding one), and proposed the existence of a hiatus between these horizons ("hiatus Post-chapadmalense", Ameghino, 1908, p. 416). Ameghino mentioned the presence of the "Horizonte Bonaerense" and "Horizonte Lujanense" as sparse isolated deposits filling the gullies and valleys created by watercourses (see Ameghino, 1908, pp. 366-380). Later, other authors (e.g. Risso Domínguez, 1949a,b; Kraglievich, 1952; Reig, 1958; Tonni et al., 1992; Cione and Tonni, 1995a, 1996) questioned the extension of the area of the Chapadmalalan sediments and, consequently, the stratigraphic reference of Ameghino (1908) for this fauna. According to Risso Domínguez (1949a,b), Ameghino (1908) overestimated the geographical extension of the "Horizonte Chapadmalalense" as he positioned these sediments between the Corrientes and Las Brusquitas streams while Risso Domínguez (1949a,b) situates these levels only between the Corrientes and Lobería creeks (Fig. 1). However, regarding the fossil materials recovered by Ameghino, Risso Domínguez (1949a:363, 1949b:427) assumed that most of these specimens underwent an accurate stratigraphic provenance since, according to him, they came from "Barranca de Los Lobos", site where this author recognized the presence of Chapadmalalan sediments. Later, Kraglievich (1952) provided a scheme of "formations" for the area and this scheme was more complex than that of Ameghino. Kraglievich (1952) took an intermediate position between Ameghino (1908) and Risso Dominguez (1949a,b) about the extension of outcrops of these sediments. According to Kraglievich, the outcrops of the sediments from the Chapadmalal "Formation" were located between the Corrientes and Loberia creeks, near "Punta Vorohue" and around Las Brusquitas creek (which includes "Barranca Parodi”, see Fig. 1). Concerning the fossil specimens collected by Ameghino (1908), Kraglievich did not agree with the interpretation of Risso Domínguez (1949a,b). He questioned the procedures carried out on the collection until then, and claimed that these fossil collections are unreliable from a stratigraphic viewpoint (Kraglievich, 1952, p. 9, in a footnote). Later, Reig 
(1958) published a new list of vertebrates of the Chapadmalal "Formation" (sensu Kraglievich, 1952) in which he excluded some taxa and incorporated others based on the new collections with stratigraphic control obtained by different naturalists (Reig, 1958:241, 245). In this context, Reig (1958) reorganized the previous faunistic list, made by contributions from the Ameghino's brothers and Kraglievich L., among others. The species P. chapalmalensis was one of the species excluded from the new list by Reig (1958: pp. 246-247). Therefore, we will not have more accurate tools to accept the stratigraphic provenance of the holotype of P. chapalmalensis (MACN-Pv 6162) until we have more precise historical information about the stratigraphic and geographical procedures.

Paraglyptodon uquiensis: According to Castellanos (1953a), the type series of this species consists of a group of specimens collected in two field trips carried out in Esquina Blanca (Quebrada de Humahuaca, Jujuy, Argentina, Fig. 1). This type series consists of the specimens collected by the naturalist Enrique De Carles in 1912: MACN-Pv 5332 (Fig. 3A), an isolated osteoderm from the caudal tube; MACN-Pv 5355 (Fig. 3B), isolated osteoderms from the dorsal carapace and the caudal tube; MACN-Pv 5377 (Fig. 4), a fragment of the skull; and MACN-Pv 5396 (Fig. 5), a proximal fragment of the left femur. The specimens collected by De Carles and Castellanos in 1921 comprise: MACN-Pv 5330 (Fig. 3C), three osteoderms from the dorsal carapace; and MACN-Pv 5344a (Fig. 3D), osteoderms from the dorsal carapace. However, according to the catalogue of the MACN Paleontology Section, the specimens that form this type series were collected during three field trips carried out in Esquina Blanca (Fig.), instead of two. In 1912, De Carles collected osteoderms from a dorsal carapace, a caudal tube and a fragment of a femur (MACN-PV 5332, 5344, 5355, 5396). Later in 1915, De Carles collected osteoderms from a dorsal carapace (MACN-PV 5330) and, finally, in 1921 De Carles and Castellanos collected a fragment of a skull (MACN-PV 5377). It is important to mention that Castellanos (1950, 1953a) recognized that part of the information of these works was based on his own memories since he did not have access to the MACN and its collection at that moment. Thus, it is feasible that the catalogue information be more accurate than that provided by Castellanos. Therefore, we are not able to establish the number of individuals involved in this association of specimens, although, there were probably at least three. Due to this fact, each specimen and its taxonomic assignment will be analyzed independently.

The terminology used for the description of the osteoderms follows Hill (2006) and Krmpotic et al. (2009), while the systematic scheme follows Fernicola (2008).

\section{Systematic paleontology}

Magnorder XENARTHRA Cope (1889).

Order CINGULATA Illiger (1811).

Suborder GLYPTODONTIA Ameghino (1889).

Superfamily GLYPTODONTOIDEA Gray (1869).

Family GLYPTODONTIDAE Gray (1869).

Subfamily GLYPTODONTINAE Gray (1869).

Glyptodontinae indet.

Referred specimens-MACN-Pv 5377, part of the type series of P. uquiensis, fragment of the skull (Fig. 4).

Description and comparisons - the preserved fragment of the skull (MACN-Pv 5377) shows part of the external surface of the restored nasal bone and nasal septum. The restoration was already present when Castellanos (1953a) published this specimen, as it agrees with a photography provided by this author. The preserved portion retains few features to support a distinction of it as being a different genus inside Glyptodontinae. Indeed, some of the features described by Castellanos (1953a) have been reconstructed or

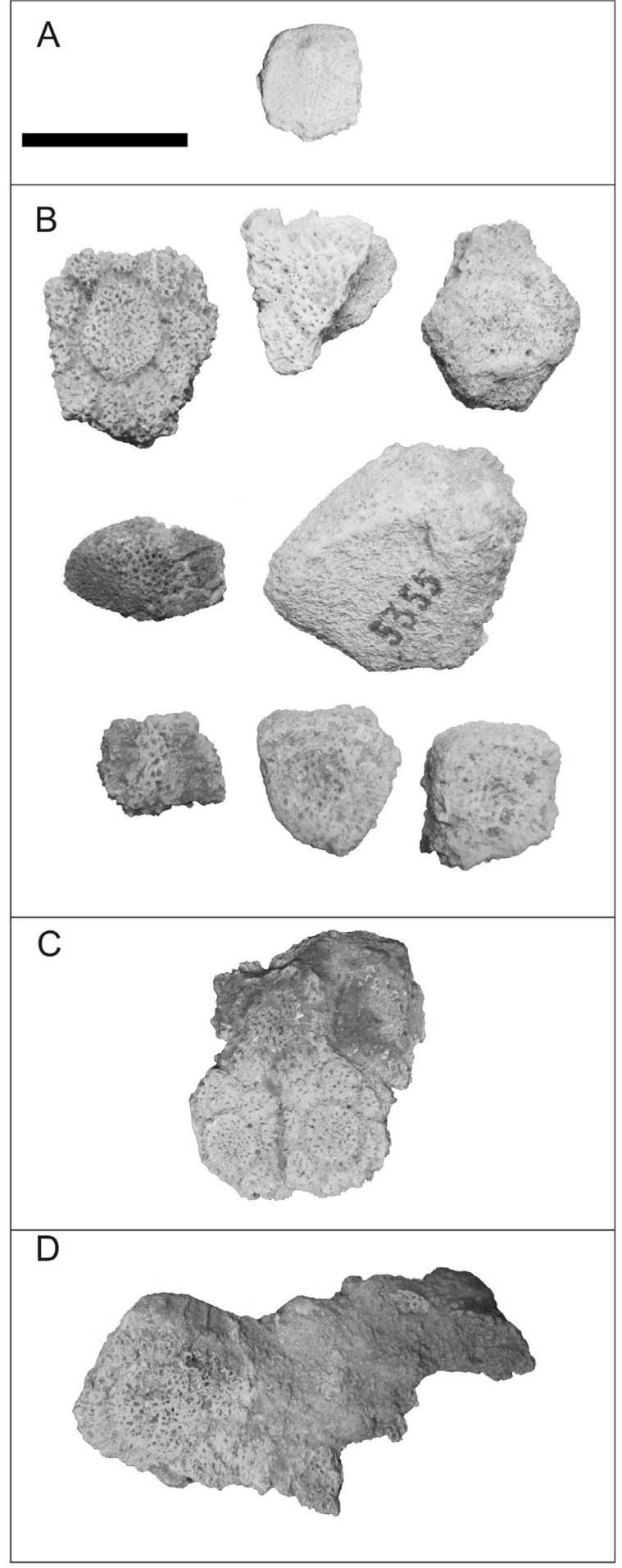

Fig. 3. Part of the type series of Paraglyptodon uquiensis MACN-PV 5332 (A); MACN-PV 5355 (B); MACN-PV 5330 (C); MACN-PV 5344a (D), osteoderms. Scale bar: $5 \mathrm{~cm}$.

estimated, e.g. the shape and length of the frontal bones, the shape of the anterior bony nasal aperture, the shape and length of the orbits, and the extent of Ml 1 and Ml 2. Within this context, the combination of two features: the trilobulation of the molariforms 2-8 while the first molariform is at least bilobulate (see Fig. 4D), and the flat (horizontal) nasal roof (Fig. 4A, B), would enable us to assign this specimen to Glyptodon. However, the presence of two very thin nasal sinuses does not allow us to make a genus 


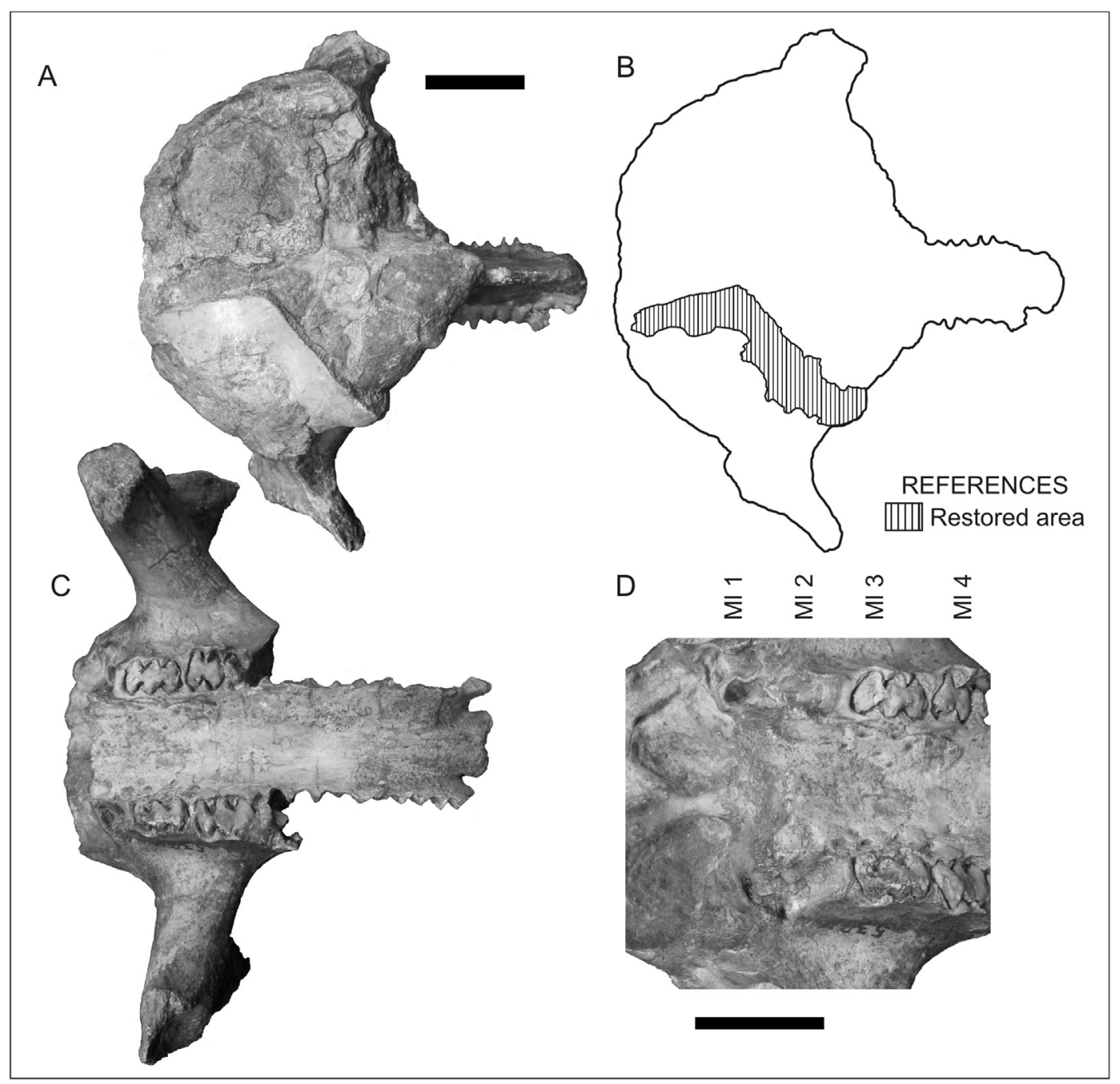

Fig. 4. Part of the type series of Paraglyptodon uquiensis MACN-PV 5377, fragment of the skull. MI, upper molariform. Scale bar: $5 \mathrm{~cm}$.

assignment, since we have not observed this structure in the one specimen of Glyptodon for which we have a CTscan. Panochthus (Panochthidae) is the other glyptodont that shows all trilobate molariforms, but in this case, the nasal bone is very slanted, and we do not know the structure and distribution of the nasal sinuses. On the other hand, it is not possible to assign this specimen to Paraglyptodon because the skull fragment has no associated osteoderms.

Genus GLYPTODON Owen, 1839.

GLYPTODON sp.

Referred specimens-MACN-Pv 6162, holotype of $P$. chapalmalensis, fragment of the dorsal carapace (Fig. 2); MACN-Pv $5330,5332,5344 a, 5355$, part of the type series of $P$. uquiensis, isolated osteoderms from the dorsal carapace and caudal tube (Fig. 3A-D); MACN-Pv 5396, part of the type series of P. uquiensis, proximal fragment of the left femur (Fig. 5).

\subsection{Description and comparisons}

Femur-The specimen MACN-Pv 5396 (Fig. 5) corresponds to the proximal half of the left femur. Almost all of the anterior and posterior surfaces and of the medial and proximal edges were reconstructed, making it very difficult to describe different anatomical accidents on such areas. One of the most important characteristics observed is the position of the greater trochanter, which is below the femoral head, feature only present in Glyptodon, Panochthus and Doedicurus. Among these taxa, the smaller size of the femur, estimated from maximum length between the major and minor trochanter (see Table 1), suggests that this taxon should be assigned to Glyptodon. On the other hand, Castellanos (1953a) considered this femur smaller and more slender than the femur of Glyptodon. However, the measurements that can be taken are inside the range of Glyptodon (Table 1), and it is noteworthy that they are almost the same as those taken by Castellanos (1953a). The differences indicated by Castellanos (1953a) regarding the morphology of the anterior and posterior faces of the femur are questionable because both faces are almost completely reconstructed (see Fig. 5) as it happened with the skull. Furthermore, it is not possible to establish if this material has the third trochanter and trochanteric fossa, because these parts are not preserved and fragmented, respectively.

Osteoderms - The osteoderms that comprise the holotype of $P$. chapalmalensis (MACN-PV 6162, Fig. 2) show on their external surface a central figure surrounded by six to seven (exceptionally eight) peripheral figures. The central figure is slightly elevated in relation to the peripheral figures, and almost all of them present a slight concavity. The central figure is separated from the peripheral figures by a wide, deep, and well-delimited central sulcus. The 


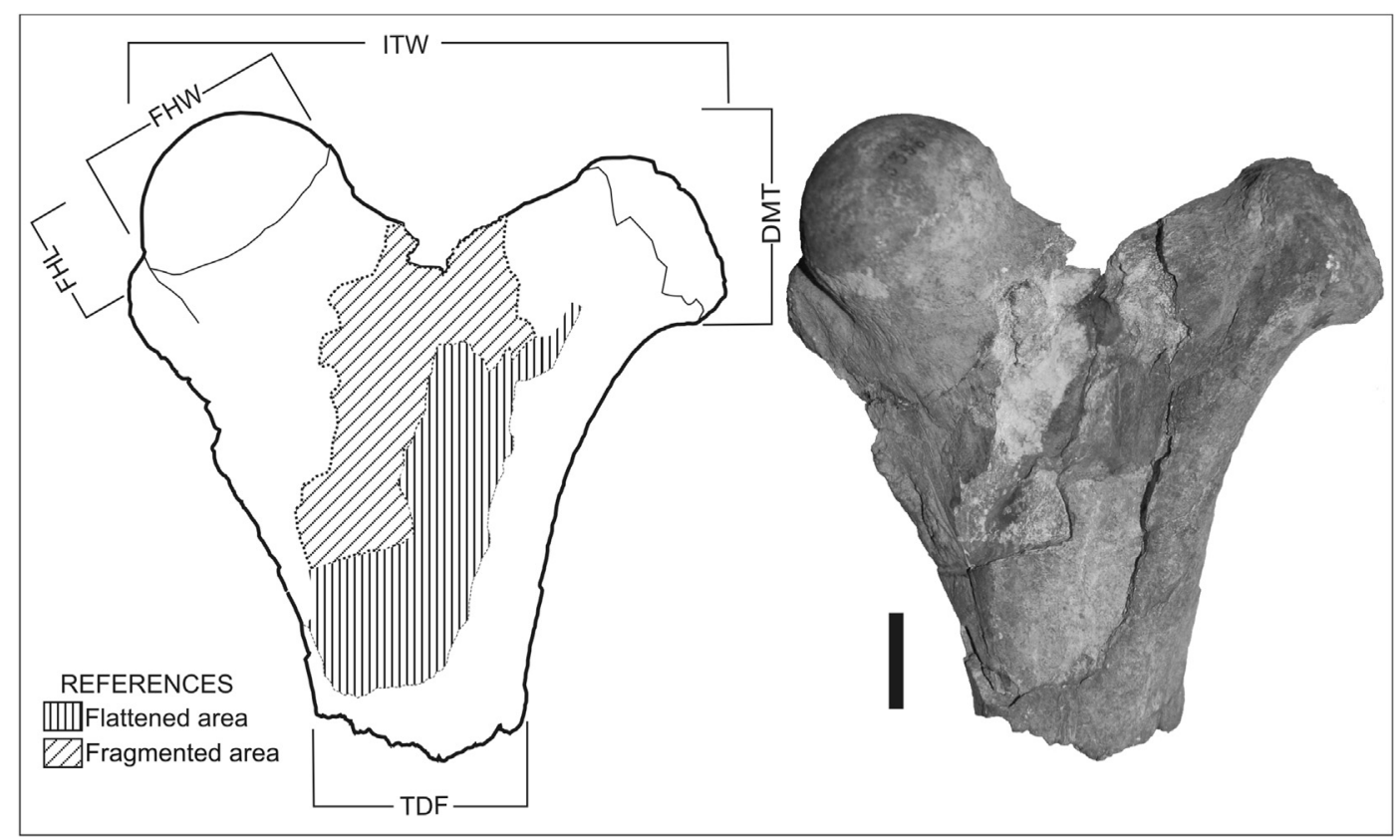

Fig. 5. Part of the type series of Paraglyptodon uquiensis MACN-PV 5396, proximal fragment of the left femur. Scale bar: $5 \mathrm{~cm}$.

Table 1

Selected measurements (in mm) of the femur MACN-PV 5396 (Paraglyptodon uquiensis), Glyptodon sp. (MACN-PV 1730), and Panochthus sp. (MACN-PV14998).

\begin{tabular}{lllrrr}
\hline Specimen & FHL & FHW & \multicolumn{1}{c}{ TDF } & \multicolumn{1}{c}{ DMT } & ITW \\
\hline MACN-PV 5396 & 58.47 & 81.95 & 94.91 & 96.62 & 235 \\
MACN-PV 1730 & 64.06 & 79.42 & 91.07 & 85.60 & 267 \\
MACN-PV 14998 & $74.46^{\text {a }}$ & 96.12 & 108.11 & $103.79^{\mathrm{a}}$ & 300 \\
\hline
\end{tabular}

Abbreviations: DMT, Distal Extension of the greater Trochanter; FHL, Femoral Head Length; FHW, Femoral Head Width; ITW, Inter-Trochanteric Width; TDF, Transverse Diameter of the mid-shaft of the Femur.

a Approximately measurements.

peripheral figures are poorly defined and separated from each other by radial sulci, which are wide but less well-delimited than the central one. In the intersection between the central and radial sulci there are large foramina. The number of foramina in each osteoderm varies between one and three. The inner surface of the osteoderms is smooth and concave. The sutures among the osteoderms are loose and, therefore, the peripheral figures between adjacent osteoderms are separated.

All of these features are present in the dorsal carapace of the juvenile specimen of Glyptodon sp. (e.g. MCA 2013, Fig. 6, Zurita et al., 2009 identified this material under the number 2017). Recently, Luna and Krapovickas (2011) described a juvenile specimen of Glyptodon sp. (MCNC-PV 246) from Córdoba province, in which this ornamentation is observable in some isolated osteoderms, and they assigned them to the middle-dorsal section.

The osteoderms that form part of the type series of $P$. uquiensis can be assigned to different parts of the exoskeleton: (MACN-Pv 5330, 5332, 5344a, 5355) (Fig. 3): (i)- two osteoderms resemble conical tubercles, one probably assigned to the posterior border or the dorsal carapace, and the other probably to the caudal tube (Fig. 3B); (ii)- five osteoderms with the typical rosette ornamentation on the external surface, one slightly concave central figure surrounded by six to eight smaller peripheral figures (although some of them are eroded), probably assigned to the dorsal region and lateral border of the carapace (Figs. 3B, C, and D); and (iii)-, finally, in the last group, there are three osteoderms with a very eroded surface, showing only a central figure with a considerably visible concavity (Fig. 3B). Thus, the carapace osteoderm morphology allows us to consider all the analyzed osteoderms as belonging to Glyptodontidae, Gliptodontinae, and within the genus Glyptodon, since every osteoderm has the typical rosette pattern, with wide and deep central and radial sulci. In contrast, in the other groups of glyptodonts that present a typical rosette pattern (Panochthidae Neosclerocalyptini and Plohophorinae Plohophorini), the central and radial sulci are very thin and shallow and, actually, the osteoderms are thinner than those of Glyptodon.

\section{Discussion and conclusion}

As a result of the revision of the holotype of $P$. chapalmalensis (MACN-Pv 6162), we recognized its morphology was also present in different specimens assigned to juvenile stages of Glyptodon sp. (e.g. MCA 2013 [Fig. 6], MCNC-PV 246, MMP 5344, MMP 5380). The central figures are concave, slightly elevated in relation to the peripheral figures and separated from them by a wide, deep, and welldelimited central sulcus. Every peripheral figure is separated from each other by wide and slightly delimited radial sulci and the sutures between osteoderms are loose, keeping the peripheral figures of adjacent osteoderms separated. All the morphological features described above and previously used as diagnostic traits for $P$. chapalmalensis were also observed in juvenile stages of Glyptodon sp. Some of these features agree with those described by Zurita (2007) and Zurita et al. (2009, 2011). These authors pointed out that the osteoderms of juvenile individuals of Glyptodon show the following features: (i) relatively small but very thick osteoderms, mostly pentagonal or hexagonal, (ii) the presence of a protruding central figure surrounded by a row of poorly defined peripheral figures, (iii) evident foramina at the intersection of the main and radial sulci, and (iv) poorly co-ossified sutures between osteoderms (Zurita et al., 2009, Fig. 2C-D; in this paper, these authors identified the material MCA 2013 as MCA 2017).

We were not able to identify characters supporting a distinction between the part of the type series of P. uquiensis and Glyptodon spp. in the compared sections (osteoderms and femur). Regarding 


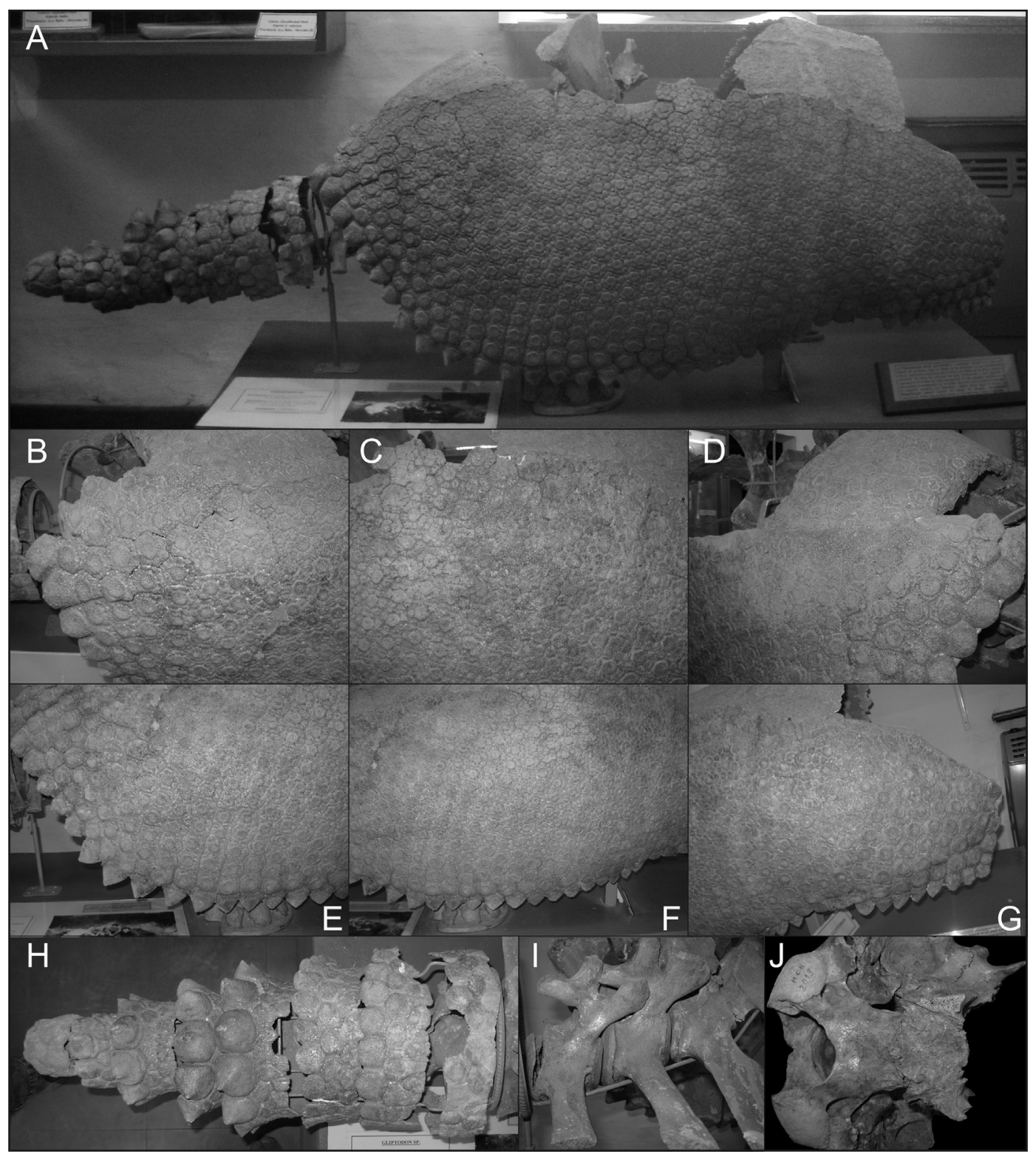

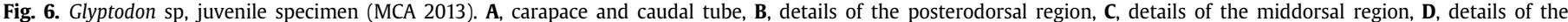

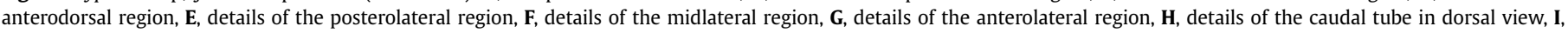
details of the caudal vertebrae, J, details of the occipital fragment of the skull in ventral view.

the fragment of skull of P. uquiensis (MACN-PV 5377), we consider it as an indeterminate Glyptodontinae, mainly based on the lobulation of the molariforms and the inclination of the external surface of the nasal region. Another feature worth commenting is the remarkable presence of a concavity in the central figure on the adult osteoderms of two of the morphotypes described above for this taxon. Ameghino (1889) described similar concavities for six species of Glyptodon within his group A, but among these species only G. clavipes and G. munizi have been, in the last decades, redescribed in amended diagnoses (Tonni and Berman, 1988; Duarte, 1997; Soibelzon et al., 2006). The group A of Ameghino (1889) has two important characteristics in their osteoderms, the central figure is larger than the peripheral figures and it has an evident concavity. Furthermore, G. munizi and G. morelloi (species described by Castellanos (1951) from Ensenadan of Córdoba, and currently under revision) have been the only species described which present dorsal osteoderms with a central figure that has an evident concavity.

From a biostratigraphic point of view, P. chapalmalensis was considered as a guide taxon of the homonymous biozone, representative of the upper Chapadmalalan Stage/Age (Cione and Tonni, 1995a,b, 1999; 2005). All the specimens previously described as Paraglyptodon were recovered from Upper Pliocene units from Mar del Plata (probably Chapadmalal Formation, Atlantic Coast, Buenos Aires, Argentina) and Esquina Blanca (Uquía Formation, North West, Jujuy, Argentina) (Castellanos, 1932, 1950, 1953a,b). Afterwards, few specimens have been assigned to Paraglyptodon, coincidentally from the same localities. From the Atlantic Coast (Mar del Plata, Buenos Aires), Reig (1958) mentioned Paraglyptodon sp. in his faunistic preliminary list. Later, Tonni et al. (1992) and Cione and Tonni (1995a,b, 1996), based either on the stratigraphic scheme of Kraglievich (1952) or on the collection mentioned by Reig (1958) and new specimens, recognized the presence of $P$. chapalmalensis in the Chapadmalal "Formation" and named one of their 
assemblages zones (Zone of $P$. chapalmalensis) after this taxon. Unfortunately, Reig (1958), Tonni et al. (1992) and Cione and Tonni (1995a,b, 1996, 1999, 2005) did not provide specific repositories or collection numbers for these materials, and, consequently, it is difficult to know where they were housed and impossible to evaluate their taxonomic assignation. Recently, Oliva et al., 2010, tentatively assigned a skull to $P$. chapalmalensis (MMP 4676), an osseous element absent in the holotype. This assignation was based on the fact that the fossil was recovered in the same lithostratigraphic unit and had a similar geographical provenance. However, this led us to consider that provenances are questionable, and, therefore, that the assignation of this material to cf. P. chapalmalensis is, at least, ambiguous. From North West of Argentina (Esquina Blanca, Jujuy), Reguero et al. (2007) and Reguero and Candela $(2008,2011)$ recovered new materials that were tentatively assigned to $P$. uquiensis. However, the only osteoderm that shows the surface is eroded, making it very difficult to support the assignation to this taxon (MLP 80-X-15-06, see Fig. 5E in Reguero and Candela, 2008).

Finally, taking into account the taxonomic proposals provided here, we consider that a new taxon guide for the Upper Chapadmalalan biozone is required for the following reasons: (i) the holotype of $P$. chapalmalensis is a juvenile specimen of Glyptodon sp.; (ii) this material underwent dubious stratigraphic an geographical provenance; and (iii) it is impossible to evaluate the taxonomic assignation of other materials from the Atlantic Coast assigned to this species (from the faunistic list of Reig (1958), Tonni et al., (1992), Cione and Tonni (1995a,b, 1996) among others) due to the absence of collection numbers. Furthermore, new discoveries in the Chapadmalal area have provided new materials of Glyptodon sp. with accurate stratigraphic and geographical provenances, including juvenile specimens (MMP 5334, 5344, 5380, 5381, 5447, $5448,5526)$, but all of these materials are commonly registered in Pleistocene levels overlaying Pliocene levels (Taglioretti M. doctoral thesis in preparation). However, the biostratrigraphic range of Glyptodon could be potentially extended to the late Pliocene, based, mainly, on materials recovered from Jujuy. Nevertheless, the scarcity of new specimens that can be undeniably assigned to the taxon indicates that new records and further studies are needed to ratify its existence in the Chapadmalalan Stage/Age in its type locality.

\section{Acknowledgments}

We thank to Alejandro G. Kramarz and Stella M. Álvarez (MACN, CABA, Argentina), Marcelo Reguero (MLP, La Plata, Buenos Aires, Argentina), Fernando Scaglia (MMP, Mar del Plata, Buenos Aires, Argentina), and José F. Bonaparte (MCA, Mercedes, Buenos Aires, Argentina), who kindly gave access to the specimens under their care. Also to Stella M. Álvarez by the preparation of the some materials for this study. Financial support for this study was provided by CONICET, ANPCyT (Agencia Nacional de Promoción Científica y Tecnológica, PICT 2012-1054 and PICT 2010-0804), UNLu (Universidad Nacional de Luján, CCD-CD: 054/12), UNLP (Universidad Nacional de La Plata, N750), and UNMDP (Universidad Nacional de Mar del Plata, PIP 382).

\section{References}

Ameghino, F., 1889. Contribución al conocimiento de los mamíferos fósiles de la República Argentina. Actas Acad. Nac. Cienc. Córdoba 6, 829-837.

Ameghino, F., 1908. Las formaciones sedimentarias de la región litoral de Mar del Plata y Chapadmalán. An. Mus. Nac. Hist. Nat. B. Aires 3 (10), 343-428.

Carlini, A.A., Scillato Yane, G.J., 1999. Evolution of Quaternary xenarthrans (Mammalia) of Argentina. In: Tonni, E.P., Cione, A.L. (Eds.), Quaternary Vertebrate Paleontology in South America, Quaternary of South America and Antarctic Peninsula, pp. 149-175. Special Volume, 12, 10.

Castellanos, A., 1932. Nuevos géneros de gliptodontes en relación con su filogenia
Physis 11 (38), 92-100.

Castellanos, A., 1950. El Uquiense, sedimentos neógenos de Uquía (Senados Perez) de la provincia de Jujuy (Argentina), pp. 1-57. Universidad Nacional del Litoral, Facultad de Ciencias Matemáticas, Físico-químicas y Naturales aplicadas a la Industria, Serie técnico-Científica, 36.

Castellanos, A., 1951. Una nueva especie de Glyptodon (G. morelloi) en el Ensenadense del Valle de Los Reartes (Sierra de Córdoba). Universidad Nacional del Litoral, Facultad de Ciencias Matemáticas, Físico-químicas y Naturales aplicadas a la Industria, pp. 1-69. Tomo VIII, Publicaciones XXXIX.

Castellanos, A., 1953a. Descripción de restos de "Paraglyptodon uquiensis" n. sp. de Uquía (Senador Pérez), Jujuy. Mem. Mus. Entre Ríos 32, 1-32 (Paleontología).

Castellanos, A., 1953b. Anotaçoes e reticaçoes ao gênero "Glyptodon" Owen e à familia "Glyptodontinae". An. Acad. Bras. Ciênc. 25 (4), 390-410.

Cione, A.L., Tonni, E.P., 1995a. Chronostratigraphy and "Land mammal-ages": the Uquian problem. J. Paleontol. 69, 135-159.

Cione, A.L., Tonni, E.P., 1995b. Bioestratigrafía y cronología del Cenozoico superior de la región pampeana. In: Alberdi, M.T., Leone, G., Tonni, E.P. (Eds.), Evolución biológica y climática de la región pampeana durante los últimos cinco millones de años. Un ensayo de correlación con el Mediterráneo occidental. Monografías CSIC, vol. 12, pp. 47-74.

Cione, A.L., Tonni, E.P., 1996. Reassesment of the Pliocene-Pleistocene continental time scale of southern South America. Correlation of the Chapadmalalan with Bolivian sections. J. S. Am. Earth Sci. 9, 221-236.

Cione, A.L., Tonni, E.P., 1999. Biostratigraphy and chronological scale of upper-most Cenozoic in the Pampean Area, Argentina. In: Tonni, E.P., Cione, A.L. (Eds.), Quaternary Vertebrate Paleontology in South America, Quaternary of South America and Antarctic Peninsula, pp. 23-51. Special Volume, 12, 3.

Cione, A.L., Tonni, E.P., 2005. Bioestratigrafía basada en mamíferos del Cenozoico superior de la provincia de Buenos Aires, Argentina. In: de Barrio, R.D. Etcheverry, R.O., Caballé, M.F., Llambías, E. (Eds.), Geología y Recursos Minerales de la Provincia de Buenos Aires. Relatorio del XVI Congreso Geológico Argentino, Cap XI, pp. 183-200.

Cope, E.D., 1889. The Edentata of North America. Am. Nat. 23, 657-664.

Duarte, R.G., 1997. Gliptodontes del Pleistoceno tardío de Aguas de las Palomas, campo del Pucará, Catamarca, Argentina. Variaciones morfológicas del caparazón de Glyptodon reticulatus Owen, 1845. Ameghiniana 34, 345-355.

Fernicola, J.C., 2008. Nuevos aportes para la sistemática de los Glyptodontia Ameghino 1889 (Mammalia, Xenarthra, Cingulata). Ameghiniana 45 (3), 553-574.

Fernicola, J.C., Porpino, K.O., 2012. Exoskeleton and systematics: a historical problem in the classification of glyptodonts. J. Mamm. Evol. 19, 171-183.

Gray, J.E., 1869. Catalogue of Carnivorous, Pachydermatous and Edentates Mammalia in the British Museum, p. 398. British Museum of Natural History.

Hill, R.V., 2006. Comparative anatomy and histology of xenarthran osteoderms. J. Morphol. 267, 1441-1460.

Illiger, J.K.W., 1811. Prodromus systemalis mammalium et avium additis terminis zoographicis utriusque classis. Berlin, p. 301.

Kraglievich, J.L., 1952. El perfil geológico de Chapadmalal y Miramar, Provincia de Buenos Aires. Rev. Mus. Munic. Cienc. Nat. Tradic. Mar del Plata 1, 8-37.

Krmpotic, C.M., Ciancio, M.R., Barbeito, C., Mario, R.C., Carlini, A.A., 2009. Osteoderm morphology in recent and fossil euphractine xenarthrans. Acta Zool. Stockh. 90, 339-351.

Luna, C.A., Krapovickas, J.M., 2011. Primer registro de un ejemplar juvenil de Glyptodon sp. (Cingulata, Glyptodontidae) del Cuaternario de la provincia de Córdoba. Mastozool. Neotropical 18, 135-141.

Oliva, C., Zurita, A.E., Dondas, A., Scillato-Yané, G.J., 2010. Los Glyptodontidae (Xenarthra, Glyptodontidae) del Piso/Edad Chapadmalalense (Plioceno tardío): revisión y aportes a su conocimiento. Rev. Mex. Cienc. Geol. 27 (1), 112-120.

Owen, R., 1839. Fossil Mammalia (2). In: Darwin, C. (Ed.), Zoology of the Voyage of H. M. S. Beagle. Smith, Elther y Co, Londres, pp. 41-64.

Reguero, M.A., Candela, A.M., 2008. Bioestratigrafía de las secuencias neógenas tardías de la Quebrada de Humahuaca, provincia de Jujuy. Implicancias paleoambientales y paleobiogeográficas. In: Relatorio del XVII Congreso Geológico Argentino, Jujuy, Argentina, pp. 286-296.

Reguero, M.A., Candela, A.M., 2011. Late Cenozoic mammals from the northwest of Argentina. In: Salfity, J.A., Marquillas, R.A. (Eds.), Cenozoic Geology of the Central Andes of Argentina: Salta. SCS Publisher, pp. 411-426.

Reguero, M.A., Candela, A.M., Alonso, R.N., 2007. Biochronology and biostratigraphy of the Uquía formation (Pliocene-early Pleistocene, NW Argentina) and its significance in the great American biotic interchange. J. S. Am. Earth Sci. 23, $1-16$.

Reig, O.A., 1958. Notas para una actualización del conocimiento de la fauna de la Formación Chapadmalal. I. Lista faunística preliminar. Acta Geol. Lillo. 2, $241-253$.

Risso Dominguez, J.D., 1949a. Estratigrafía de las Barrancas de Chapadmalal y Vorohué. Notas preliminares a un estudio detallado de las mismas. Estudios 81 (440), 353-372.

Risso Dominguez, J.D., 1949b. Estratigrafía de las Barrancas de Chapadmalal y Vorohué. La estratigrafía de Ameghino en las costas de Chapadmalal y Vorohue. Estudios 81 (441), 419-431.

Rovereto, C., 1914. Los estratos araucanos y sus fósiles. An. Mus. Nac. Hist. Nat. B. Aires 25, 250.

Scillato-Yané, G.J., Carlini, A.A., Vizcaíno, S.F., Ortiz Jaureguizar, E., 1995. Los Xenarthros. In: Alberdi, M.T., Leone, G., Tonni, E.P. (Eds.), Evolución Biológica y Climática de la Región Pampeana durante los últimos cinco millones de años. Un ensayo de correlación con el mediterráneo Occidental. Madrid, pp. 180-209. 
Soibelzon, E., Zurita, A.E., Carlini, A.A., 2006. Glyptodon munizi ameghino (Mammalia, cingulata, glyptodontidae): redescripción y anatomía. Ameghiniana 43 (2), 377-384.

Tonni, E.P., Berman, W., 1988. Sobre dos especies de Glyptodon (Mammalia, Cingulata) del Pleistoceno tardío de la provincia de Buenos Aires. Su importancia bioestratigráfica. 2ºrnadas Geológicas Bonaerenses. Actas 109-116.

Tonni, E.P., Alberdi, M.T., Prado, J.L., Bargo, M.S., Cione, A.L., 1992. Changes of mammal assemblages in the Pampean region (Argentina) and their relation with the Plio-Pleistocene boundary. Palaeoecol. Palaeogeogr. Palaeoclimatol. 95, 179-194.

Zurita, A.E., 2007. Los Hoplophorini (Xenarthra, Glyptodontidae) del "Araucanense"
(Mioceno tardío-Plioceno) del noroeste de la Argentina: sistemática, paleobiogeografía y paleoambientes. Ameghiniana 44 (2), 257-269.

Zurita, A.E., Miño-Boilini, Á.R., Soibelzon, E., Carlini, A.A., Paredes Ríos, F., 2009. The diversity of Glyptodontidae (Xenarthra, Cingulata) in the Tarija Valley (Bolivia) systematic, biostratigrphic and paleobiogeographic aspects of a particular assemblage. Neues Jahrb. Geol. Paläontologie. Abh 251 (2), 225-237.

Zurita, A.E., Oliveira, E.V., Toriño, P., Rodriguez-Bualó, S.M., Scillato-Yané, G.J., Luna, C.A., Krapovickas, J.M., 2011. On the taxonomic status of some Glyptodontidae (Mammalia, Xenarthra, Cingulata) from the Pleistocene of South America. Ann. Paléontol. 97, 63-83. 